-judicially murdered, I must say-pass under the eye of any relatives of the parties to this tragedy, they will pardon the warmth and zeal of an old man still shocked by the recollection of so sad a sacrifice of human life! Quiescant omnes in pace!

\title{
MRS. DR. DUNLAP INSTANTLY KILLED
}

\author{
BY HER HORSE BACKING AT THE TOWNSEND STREET CROSSING AND AN \\ EXPRESS TRAIN RUNNING DOWN HER SLEIGH.
}

A terrible casualty occurred this afternoon on the West Shore railroad, at the Townsend street crossing, in the Fourth Ward, just east of the Unitarian Church, by which Mrs. Dr. Joseph P. Dunlap, was instantly killed. The particulars of the occurrence are as follows :-

Mrs. Dunlap left home on Fayette Park, soon after two o'clock, in her sleigh, to go to a meeting of the Fireside Traveler's Club at Mrs. A. C. Chase's, 80 James street. In crossing the West Shore railroad track at Townsend street, the horse balked, and the Buffalo express train on the West Shore, coming from the east, at 2:34 Р. M., ran into the sleigh, crushing it, and throwing Mrs. Dunlap on to the track, and the locomotive and train passed over her, crushing her head and instantly killing her. Her left arm was crushed from the elbow to the shoulder. There appear to be no other injuries to her person. John West, the driver of the horse, was thrown to one side of the track, and his skull was lacerated and his right leg broken. The horse broke loose and escaped unhurt.

Mrs. Dunlap was the wife of Dr. Joseph P. Dunlap, one of our oldest citizens and best known physicians. She was 57 years of age, and had been a resident of this city for upwards of thirty-five years. She came here from Boston as a teacher. She was one of the most accomplished and winsome ladies in the society of Syracuse, an active promoter of good works, and always engaged in benevolent and charitable enterprises.

She had two sons, Dr. Herbert W. Dunlap, who is his father's partner; and a younger son, Irving $H$., who recently went to Kansas to engage in cattle raising.

The intelligence of this terrible occurrence rapidly spread throughout the community, and created a very profound impression. The death of no other lady in this city could be more deeply mourned, and the universal sympathy will be extended to the sorely bereaved family.Syracuse Daily Journal, Monday, Jan. 7, 1884. 
Copyright of Annals of Iowa is the property of State of Iowa, by \& through the State Historical Society of Iowa and its content may not be copied or emailed to multiple sites or posted to a listserv without the copyright holder's express written permission. However, users may print, download, or email articles for individual use. 